\title{
Flavobacterium fluvii sp. nov., isolated from stream sediment
}

\author{
Se Hee Lee, ${ }^{1}$ Jeong Myeong Kim, ${ }^{1}$ Jung Ro Lee, ${ }^{2}$ Woojun Park ${ }^{3}$ \\ and Che Ok Jeon ${ }^{1}$ \\ ${ }^{1}$ Department of Life Science, Chung-Ang University, Seoul, 156-756, Republic of Korea \\ ${ }^{2}$ Environmental Biotechnology National Core Research Center, Gyeongsang National University, \\ Jinju, 660-701, Republic of Korea \\ ${ }^{3}$ Division of Environmental Science and Ecological Engineering, Korea University, Seoul, 136-701, \\ Republic of Korea
}

Correspondence

Che Ok Jeon

cojeon@cau.ac.kr

\begin{abstract}
An aerobic, yellow-pigmented, Gram-staining-negative bacterium, designated strain $\mathrm{H}^{\top}$, was isolated from sediment of Gazwa stream in Jinju city, South Korea. Cells of strain $\mathrm{H}^{\top}$ were nonmotile, straight rods that produced flexirubin pigments and showed catalase- and oxidase

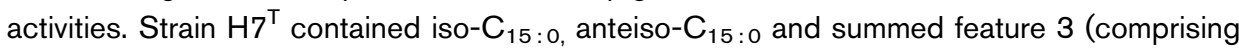
$\mathrm{C}_{16: 1} \omega 7 \mathrm{c}$ and/or iso- $\left.\mathrm{C}_{15: 0} 2-\mathrm{OH}\right)$ as the main fatty acids and menaquinone-6 (MK-6) as the major isoprenoid quinone. The DNA G $+\mathrm{C}$ content of strain $\mathrm{H}^{\top}$ was $37.2 \mathrm{~mol} \%$. Comparative 16S rRNA gene sequence analysis showed that strain $\mathrm{H}^{\top}$ formed a distinct phyletic line within the genus Flavobacterium. Based on 16S rRNA gene sequence similarities, the novel strain was most closely related to Flavobacterium limicola ST-82 ${ }^{\top}$ and Flavobacterium resistens BD-b365 ${ }^{\top}$ with $97.2 \%$ and $97.0 \%$ gene sequence similarities, respectively. The DNA-DNA relatedness of the novel strain with these species was only $18 \%$ and $14 \%$, respectively. On the basis of phenotypic data and molecular properties, strain $\mathrm{H} 7^{\top}$ represents a novel species within the genus Flavobacterium, for which the name Flavobacterium fluvii sp. nov. is proposed. The type strain is $\mathrm{H} 7^{\top}$ (=KACC $12818^{\top}=$ DSM $19978^{\top}$ ).
\end{abstract}

The genus Flavobacterium, which belongs to the family Flavobacteriaceae, phylum Bacteroidetes, was proposed by Bergey et al. (1923) and the description was considerably emended by Bernardet et al. (1996). The genus Flavobacterium comprises Gram-staining-negative, strictly aerobic, predominantly gliding, pigmented rods with menaquinone-6 (MK-6) as the major respiratory quinone and with DNA G + C contents of between 30 and $41 \mathrm{~mol} \%$ (Bernardet \& Bowman, 2006; Park et al., 2006). Species of the genus Flavobacterium with diverse physiological characteristics have been isolated from varied habitats such as microbial mats, freshwater and seawater, Antarctic lakes, green house soil, beaked whales, earthworm gut and contaminated sediments (McCammon \& Bowman, 2000; Humphry et al., 2001; Tamaki et al., 2003; Van Trappen et al., 2005; Cousin et al., 2007; Park et al., 2007; Ryu et al., 2007, 2008; Vela et al., 2007; Weon et al., 2007; Jit et al., 2008). This suggests that they may have important roles in the environment. The taxonomic characterization of a

Abbreviations: ML, maximum-likelihood; MP, maximum-parsimony; NJ, neighbour-joining.

The GenBank/EMBL/DDBJ accession number for the 16S rRNA gene sequence of strain $\mathrm{H}^{\top}$ is EU109724. novel species belonging to the genus Flavobacterium is reported in this paper.

Soil sediment was collected from the Gazwa stream in Jinju city $\left(35^{\circ} 11^{\prime} \mathrm{N} 128^{\circ} 05^{\prime} \mathrm{E}\right)$ in Gyeongnam province, South Korea. The sediment was diluted serially using $0.9 \%(\mathrm{w} / \mathrm{v})$ saline and diluted solutions were spread on R2A agar (Difco) plates and incubated at $25{ }^{\circ} \mathrm{C}$ for 5 days. Strain $\mathrm{H}^{\mathrm{T}}$ was isolated and routinely grown on R2A agar aerobically at $30{ }^{\circ} \mathrm{C}$ for 3 days, except where indicated otherwise. The strain was stored at $-80{ }^{\circ} \mathrm{C}$ in R2A broth supplemented with $10 \%(\mathrm{v} / \mathrm{v})$ glycerol for preservation.

Amplification and sequencing of the 16S rRNA gene of strain $\mathrm{H}^{\mathrm{T}}$ was carried out as described by Kim et al. (2008). Briefly, a single colony grown on R2A agar was resuspended in $100 \mu \mathrm{l} 5 \%(\mathrm{w} / \mathrm{v})$ Chelex-100 solution (Bio$\mathrm{Rad}$ ) and boiled for $10 \mathrm{~min}$ to prepare crude genomic DNA lysates. PCR amplification of 16S rRNA genes from the crude lysates was performed using the universal primer F1 (5'-AGAGTTTGATCMTGGCTCAG-3') and R13 (5'TACGGYTACCTTGTTACGACTT- $3^{\prime}$ ) as described previously (Lu et al., 2006). The resulting 16S rRNA gene sequence (1479 nucleotides) was checked manually for quality and gaps and compared with sequences from 
GenBank using the BLAST program (http://www.ncbi.nlm. nih.gov/BLAST/) to determine an approximate phylogenetic affiliation. It was then aligned with sequences of closely related members of the family Flavobacteriaceae by using CLUSTAL W software (Thompson et al., 1994). The sequence similarity values between the new isolate and related bacteria were evaluated using the EzTaxon Server (http:// www.eztaxon.org/; Chun et al., 2007). Phylogenetic trees were constructed by using the neighbour-joining (NJ), maximum-likelihood (ML) and maximum-parsimony (MP) algorithms available in the PHYLIP software, version 3.6 (Felsenstein, 2002). The resulting tree topologies were evaluated using bootstrap analysis based on 1000 resampled datasets with the PHYLIP package.

DNA-DNA hybridization was carried out to evaluate the genomic DNA relatedness between strain $\mathrm{H}^{\mathrm{T}}$ and the related strains Flavobacterium limicola ST $-82^{\mathrm{T}}$ and Flavobacterium resistens $\mathrm{BD}-\mathrm{b} 365^{\mathrm{T}}$ using the fluorometric microplate method (Ezaki et al., 1989). Fluorometric data recorded after reaction of the substrates for $30 \mathrm{~min}$ were used for the calculation of DNA-DNA hybridization values. The signals produced by homologous reactions were inferred as $100 \%$ and percentages of DNA-DNA relatedness were calculated from the mean values of five replications.

Phylogenetic analysis based on 16S rRNA gene sequences indicated that strain $\mathrm{H}^{\mathrm{T}}$ formed a distinct phylogenetic line within the genus Flavobacterium (Fig. 1), although the bootstrap value was low (16.5\%). The overall topology of the ML and MP trees was essentially the same as that of the $\mathrm{NJ}$ tree (data not shown). Comparative 16S rRNA gene sequence analysis showed that the new isolate was most closely related to F. limicola $\mathrm{ST}-82^{\mathrm{T}}$ and $F$. resistens $\mathrm{BD}-$ b365 ${ }^{\mathrm{T}}$ with similarities of $97.2 \%$ and $97.0 \%$, respectively. The 16S rRNA gene sequence similarities of the new isolate with other species of the genus Flavobacterium were less than $97.0 \%$. The DNA-DNA relatedness values for strain $\mathrm{H} 7^{\mathrm{T}}$ with F. limicola $\mathrm{ST}-82^{\mathrm{T}}$ and F. resistens $\mathrm{BD}-\mathrm{b} 365^{\mathrm{T}}$ were $18 \%$ and $14 \%$, respectively, which are clearly below the $70 \%$ threshold generally accepted for species delineation (Rosselló-Mora \& Amann, 2001).

Growth was tested on R2A, Luria-Bertani (LB), tryptic soy (TSA, Difco) and nutrient (NA, Difco) agars at $30{ }^{\circ} \mathrm{C}$. Temperatures and $\mathrm{pH}$ values for growth of strain $\mathrm{H}^{\mathrm{T}}$ were examined by growing the isolate on $\mathrm{R} 2 \mathrm{~A}$ agar at $5-35^{\circ} \mathrm{C}$ at $5{ }^{\circ} \mathrm{C}$ intervals and in R2A broth adjusted to $\mathrm{pH} 5.0-10.0$ at $0.5 \mathrm{pH}$ unit intervals for 5 days. The $\mathrm{pH}$ was adjusted prior to sterilization by the addition of $\mathrm{HCl}$ or $\mathrm{NaOH}$ and measured again after sterilization. Gram staining was performed using the bioMérieux Gram Stain kit according to the manufacturer's instructions. Cell morphology, the presence of flagella and gliding motility were studied using phase-contrast microscopy and transmission electron microscopy (JEM-1010; JEOL) as described previously (Bernardet et al., 2002; Jeon et al., 2004). Salt tolerance was tested in R2A broth prepared with $0-3 \%(w / v) ~ N a C l$ at

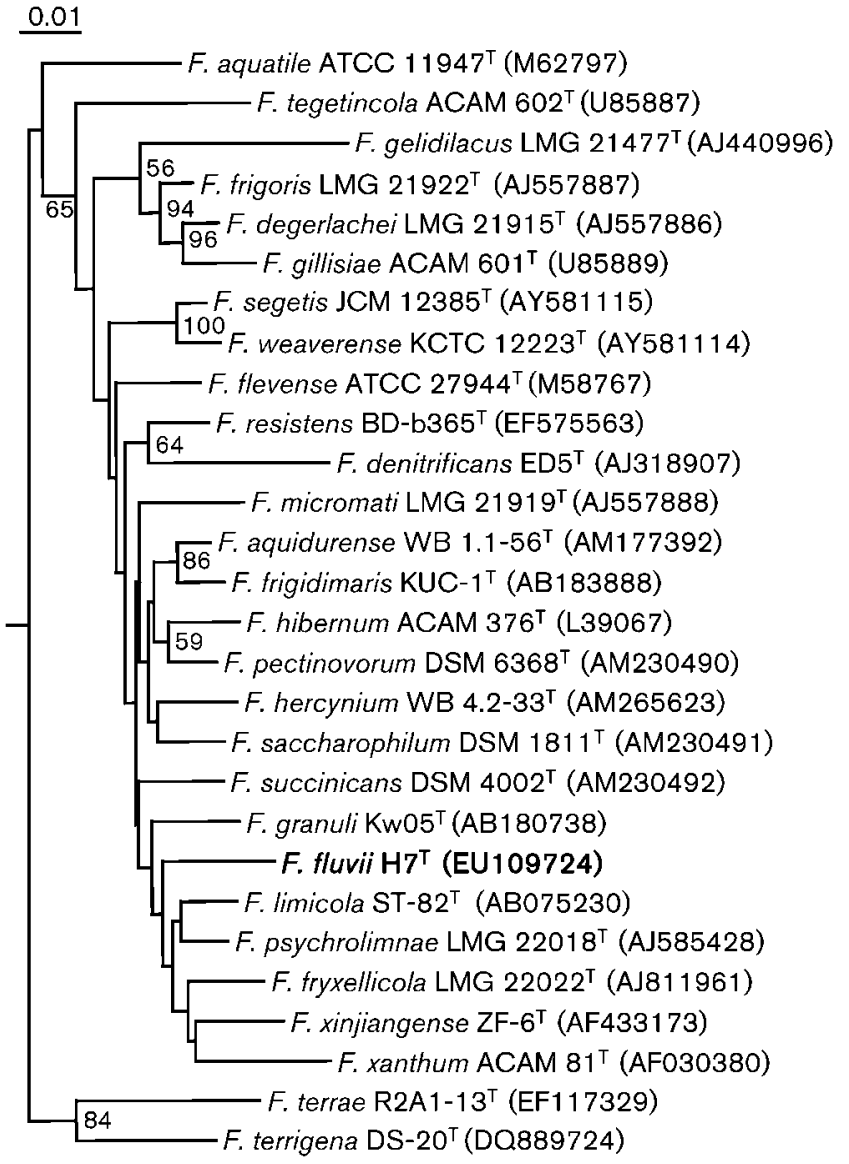

Fig. 1. Neighbour-joining tree based on 16S rRNA gene sequences showing the phylogenetic relationships of strain $\mathrm{H}^{\top}$ and related taxa. Bootstrap values $>50 \%$ are shown as percentages of 1000 replicates. Capnocytophaga granulosa LMG $16022^{\top}$ (U41347) was used as an outgroup (not shown). Bar, 0.01 changes per nucleotide position.

$0.5 \%$ intervals for 5 days at $30{ }^{\circ} \mathrm{C}$. Oxidase activity was tested by oxidation of $1 \%(\mathrm{w} / \mathrm{v})$ tetramethyl-p-phenylenediamine (Merck) and catalase activity was evaluated by the production of oxygen bubbles in $3 \%(\mathrm{v} / \mathrm{v})$ aqueous hydrogen peroxide solution. The production of flexirubin type pigments and of extracellular glycans was investigated using the $\mathrm{KOH}$ and Congo red tests, respectively, following the minimal standards for the description of new taxa in the family Flavobacteriaceae (Bernardet et al., 2002). Nitrate reduction was assessed according to the method of Lányí (1987) and acid production from carbohydrates was tested as described by Leifson (1963). Antibiotic susceptibility tests were performed in duplicate on R2A agar at $30{ }^{\circ} \mathrm{C}$ for 3 days using filter-paper discs (diameter, $8 \mathrm{~mm}$ ) containing the following antibiotics ( $\mu \mathrm{g}$ per disc unless otherwise indicated): ampicillin (10), polymyxin B $(100 \mathrm{U})$, streptomycin (50), penicillin $\mathrm{G}(10 \mathrm{U})$, gentamicin (30), chloramphenicol (100), tetracycline (30), kanamycin (30), lincomycin (15), oleandomycin (15), 
carbenicillin (100) and novobiocin (50). Hydrolysis of carboxylmethylcellulose, aesculin, casein, Tween 80 , Tween 20, tyrosine, gelatin and starch was investigated on R2A agar after a 7-day incubation and was conducted according to previously described methods (Lányí, 1987; Smibert \& Krieg, 1994). Additional enzymic activities and biochemical features were determined using API ZYM, API 20NE and API 20E kits (bioMérieux) and the utilization or oxidation of carbon sources was determined using the GN MicroPlate system (Biolog) according to the manufacturers' instructions. Anaerobic growth was assessed on R2A agar under anaerobic (with 4-10\% $\mathrm{CO}_{2}$ ) conditions using the GasPak Plus system (BBL) at $30{ }^{\circ} \mathrm{C}$ for 15 days. The hydrolysis and utilization tests were performed in parallel on strain $\mathrm{H}^{\mathrm{T}}$ and on the type strains of its closest phylogenetic neighbours F. limicola $\mathrm{ST}-82^{\mathrm{T}}$, F. resistens $\mathrm{BD}-$ b365 ${ }^{\mathrm{T}}$, Flavobacterium psychrolimnae LMG $22018^{\mathrm{T}}$ and Flavobacterium xinjiangense JCM $11314^{\mathrm{T}}$.

Strain $\mathrm{H}^{\mathrm{T}}$ grew at $30{ }^{\circ} \mathrm{C}$ on $\mathrm{R} 2 \mathrm{~A}, \mathrm{LB}$, TSA and nutrient (NA, Difco) agars. The new isolate grew optimally in $\mathrm{R} 2 \mathrm{~A}$ broth without the addition of $\mathrm{NaCl}$ and growth was severely inhibited in the presence of $>1 \%(\mathrm{w} / \mathrm{v}) \mathrm{NaCl}$. Anaerobic growth was not observed after 15 days at $30{ }^{\circ} \mathrm{C}$ on R2A agar. The phenotypic features of strain $\mathrm{H} 7^{\mathrm{T}}$ are presented in Table 1 and in the species description. Some of them were in accordance with the characteristics of members of the genus Flavobacterium, whereas others enabled the differentiation of strain $\mathrm{H}^{\mathrm{T}}$ from closely related species of the genus Flavobacterium (Table 1).

Isoprenoid quinones were analysed using HPLC (LC-20A; Shimadzu) equipped with a diode array detector (SPDM20A; Shimadzu) and a reversed-phase column $(250 \times 4.6 \mathrm{~mm}$; Kromasil, Akzo Nobel) as described previously (Komagata \& Suzuki, 1987). Cellular fatty acid analysis using cells grown on NA plates at $20{ }^{\circ} \mathrm{C}$ for $3-$ 5 days was performed in parallel for strain $\mathrm{H}^{\mathrm{T}}$ and the type strains of its closest phylogenetic neighbours $F$. limicola $\mathrm{ST}-82^{\mathrm{T}}, F$. resistens $\mathrm{BD}-\mathrm{b} 365^{\mathrm{T}}, F$. xinjiangense JCM $11314^{\mathrm{T}}$ and F. psychrolimnae LMG $22018^{\mathrm{T}}$. However, F. xinjiangense JCM $11314^{\mathrm{T}}$ was cultivated at $12{ }^{\circ} \mathrm{C}$ for 5 days for the cellular fatty acid analysis because this strain does not grow at $20{ }^{\circ} \mathrm{C}$ (Zhu et al., 2003). Analysis of fatty acid methyl esters was performed according to the instructions of the Microbial Identification System (MIDI; Microbial ID, Inc.). The DNA G $+\mathrm{C}$ content of strain $\mathrm{H}^{\mathrm{T}}$ was determined using HPLC with a reversedphase column (GROM-SIL 100 ODS-2FE; GROM) according to the method of Tamaoka \& Komagata (1984). The major respiratory lipoquinone of strain $\mathrm{H}^{\mathrm{T}}$ was menaquinone-6 (MK-6). The major cellular fatty acids were iso- $\mathrm{C}_{15: 0}(18.2 \%)$, anteiso- $\mathrm{C}_{15: 0}(15.6 \%)$, summed feature 3 (comprising $\mathrm{C}_{16: 1} \omega 7 c$ and/or iso- $\mathrm{C}_{15: 0} 2-\mathrm{OH}$, $9.1 \%)$, iso- $\mathrm{C}_{17: 0} 3-\mathrm{OH}(6.2 \%)$ and iso- $\mathrm{C}_{15: 0} 3-\mathrm{OH}$ (6.1\%). The complete fatty acid contents of strain $\mathrm{H}^{\mathrm{T}}$ and its closest phylogenetic neighbours are given in Table 2. The DNA G $+\mathrm{C}$ content of strain $\mathrm{H}^{\mathrm{T}}$ was $37.2 \mathrm{~mol} \%$. The
Table 1. Differential characteristics of strain $\mathrm{H}^{\top}$ and closely related species of the genus Flavobacterium

Strains: $1, \mathrm{H}^{\mathrm{T}}$ (this study); 2, F. limicola ST-82 ${ }^{\mathrm{T}}$ (Tamaki et al., 2003); 3, F. resistens BD-b365 ${ }^{\mathrm{T}}$ (Ryu et al., 2008); 4, F. psychrolimnae LMG $22018^{\mathrm{T}}$ (Van Trappen et al., 2005); 5, F. xinjiangense JCM $11314^{\mathrm{T}}$ (Zhu et al., 2003). All strains are positive for the following characteristics: catalase, oxidase, hydrolysis of aesculin, utilization (Biolog) of $\alpha$-cyclodextrin, dextrin, glycogen, cellobiose, $\alpha$-D-glucose, maltose, turanose, glycyl-L-aspartic acid, L-ornithine, L-proline, Lthreonine, uridine, glucose 1-phosphate and glucose 6-phosphate. All strains are negative for the following characteristics: Gram staining, nitrate reduction, hydrolysis of Tween 40, Tween 80, citrate and CMcellulose, utilization (Biolog) of Tween 80, D-arabitol, D-erythritol, Dgalactonic acid lactone, cis-aconitic acid, D-glucosaminic acid, $p$ hydroxyphenylacetic acid, L-pyroglutamic acid, D-serine, DL-carnitine, 2-aminoethanol, 2,3-butanediol and glycerol. +, Positive; -, negative; $(+)$, weakly positive.

\begin{tabular}{|c|c|c|c|c|c|}
\hline Characteristic & 1 & 2 & 3 & 4 & 5 \\
\hline Gliding motility & - & - & + & - & - \\
\hline Flexirubin type pigments & + & - & + & - & - \\
\hline \multicolumn{6}{|l|}{ Growth on: } \\
\hline Nutrient agar ${ }^{\star}$ & + & + & + & + & + \\
\hline Trypticase soy agar & + & + & + & + & - \\
\hline Growth at $20{ }^{\circ} \mathrm{C}$ & + & + & + & + & - \\
\hline $\begin{array}{l}\beta \text {-Galactosidase activity (API } \\
20 \mathrm{E})^{*}\end{array}$ & + & - & + & - & - \\
\hline $\mathrm{H}_{2} \mathrm{~S}$ production (API $\left.20 \mathrm{E}\right)^{*}$ & - & - & - & - & + \\
\hline \multicolumn{6}{|l|}{ Hydrolysis of:* } \\
\hline Casein & - & + & + & + & + \\
\hline Gelatin & - & + & - & - & + \\
\hline Starch & - & + & + & + & - \\
\hline Tyrosine & - & + & - & - & - \\
\hline \multicolumn{6}{|l|}{ Utilization (Biolog) of: ${ }^{*}$} \\
\hline Acetic acid & $(+)$ & + & + & + & $(+)$ \\
\hline$N$-Acetyl D-galactosamine & + & - & - & - & $(+)$ \\
\hline L-Arabinose & + & - & $(+)$ & - & - \\
\hline D-Arabitol & - & - & - & - & $(+)$ \\
\hline Gentiobiose & + & $(+)$ & + & - & + \\
\hline D-Mannitol & - & - & - & - & $(+)$ \\
\hline Melibiose & $(+)$ & + & + & + & $(+)$ \\
\hline Methyl $\beta$-D-glucoside & - & - & + & - & + \\
\hline L-Rhamnose & + & - & - & - & - \\
\hline Sucrose & + & $(+)$ & - & $(+)$ & + \\
\hline DNA G $+\mathrm{C}$ content $(\mathrm{mol} \%)$ & 37.2 & 35.0 & 35.4 & 34.5 & 34.4 \\
\hline
\end{tabular}

${ }^{\star}$ All results from this study.

major lipoquinone, major fatty acids and DNA $\mathrm{G}+\mathrm{C}$ content were in line with those of members of the genus Flavobacterium (Tamaki et al., 2003; Zhu et al., 2003; Bernardet \& Bowman, 2006; Vela et al., 2007). Therefore, the physiological, biochemical and phylogenetic properties of strain $\mathrm{H7}^{\mathrm{T}}$ support its description as a novel species within the genus Flavobacterium, for which the name Flavobacterium fluvii sp. nov. is proposed. 
Table 2. Cellular fatty acid contents (\%) of strain $\mathrm{H} 7^{\top}$ and closely related species of the genus Flavobacterium

Strains: $1, \mathrm{H}^{\mathrm{T}} ; 2$, F. limicola ST $-82^{\mathrm{T}} ; 3$, F. resistens $\mathrm{BD}-\mathrm{b} 365^{\mathrm{T}} ; 4, \mathrm{~F}$. psychrolimnae LMG $22018^{\mathrm{T}} ; 5$, F. xinjiangense JCM $11314^{\mathrm{T}}$. All data are from this study. Data are expressed as percentages of total fatty acids. Fatty acids amounting to $<1.0 \%$ in all strains are not shown. tr, Trace amount $(<1 \%)$; - , not detected; ECL, equivalent chainlength.

\begin{tabular}{|c|c|c|c|c|c|}
\hline Fatty acid & 1 & 2 & 3 & 4 & 5 \\
\hline \multicolumn{6}{|l|}{ Straight chain: } \\
\hline $\mathrm{C}_{14: 0}$ & 1.1 & $\operatorname{tr}$ & $\operatorname{tr}$ & $\operatorname{tr}$ & $\operatorname{tr}$ \\
\hline $\mathrm{C}_{15: 0}$ & 3.4 & 4.0 & 10.0 & 4.1 & 7.7 \\
\hline $\mathrm{C}_{16: 0}$ & 1.7 & $\operatorname{tr}$ & 1.7 & 1.2 & $\operatorname{tr}$ \\
\hline \multicolumn{6}{|l|}{ Branched: } \\
\hline iso- $\mathrm{C}_{13: 0}$ & 2.6 & $\operatorname{tr}$ & $\operatorname{tr}$ & $\operatorname{tr}$ & $\operatorname{tr}$ \\
\hline iso- $\mathrm{C}_{14: 0}$ & - & 3.5 & $\operatorname{tr}$ & 3.1 & 2.5 \\
\hline iso- $\mathrm{C}_{15: 0}$ & 18.2 & 16.0 & 33.2 & 13.2 & 10.0 \\
\hline iso- $\mathrm{C}_{15: 1} \mathrm{G}$ & 4.9 & 7.0 & 2.2 & 6.0 & 6.2 \\
\hline iso- $\mathrm{C}_{16: 0}$ & $\operatorname{tr}$ & 3.7 & 1.7 & 4.2 & 2.5 \\
\hline iso- $\mathrm{C}_{16: 1} \mathrm{H}$ & 1.0 & 5.4 & $\operatorname{tr}$ & 5.4 & 2.8 \\
\hline iso- $\mathrm{C}_{17: 1} \omega 9 c$ & 1.3 & 6.7 & 4.9 & 5.1 & 2.0 \\
\hline anteiso- $\mathrm{C}_{13: 0}$ & 3.1 & - & - & - & - \\
\hline anteiso- $\mathrm{C}_{15: 0}$ & 15.6 & 4.0 & 2.7 & 4.3 & 4.6 \\
\hline anteiso- $\mathrm{C}_{15: 1} \mathrm{~A}$ & 2.7 & $\operatorname{tr}$ & - & $\operatorname{tr}$ & $\operatorname{tr}$ \\
\hline anteiso- $\mathrm{C}_{17: 1} \omega 9 c$ & 1.9 & - & - & - & - \\
\hline \multicolumn{6}{|l|}{ Unsaturated: } \\
\hline $\mathrm{C}_{15: 1} \omega 6 c$ & 2.3 & 6.8 & 5.6 & 6.2 & 10.4 \\
\hline $\mathrm{C}_{17: 1} \omega 6 c$ & 2.1 & 6.1 & 1.8 & 6.4 & 9.8 \\
\hline $\mathrm{C}_{18: 1} \omega 5 c$ & - & 1.0 & $\operatorname{tr}$ & 1.2 & $\operatorname{tr}$ \\
\hline \multicolumn{6}{|l|}{ Hydroxy: } \\
\hline $\mathrm{C}_{15: 0} 3-\mathrm{OH}$ & - & - & - & - & 1.5 \\
\hline $\mathrm{C}_{16: 0} 3-\mathrm{OH}$ & 1.7 & $\operatorname{tr}$ & 1.6 & $\operatorname{tr}$ & 1.7 \\
\hline $\mathrm{C}_{17: 0} 2-\mathrm{OH}$ & 2.5 & $\operatorname{tr}$ & $\operatorname{tr}$ & - & $\operatorname{tr}$ \\
\hline iso- $\mathrm{C}_{15: 0} 3-\mathrm{OH}$ & 6.1 & 5.1 & 8.4 & 5.5 & 3.8 \\
\hline iso- $\mathrm{C}_{16: 0} 3-\mathrm{OH}$ & 3.5 & 6.2 & 1.5 & 6.4 & 4.5 \\
\hline iso- $\mathrm{C}_{17: 0} 3-\mathrm{OH}$ & 6.2 & 4.4 & 6.9 & 4.4 & 3.4 \\
\hline \multicolumn{6}{|l|}{ Summed features ${ }^{*}$} \\
\hline 3 & 9.1 & 9.7 & 5.7 & 11.9 & 14.9 \\
\hline 4 & - & 1.6 & 2.6 & 1.7 & - \\
\hline \multicolumn{6}{|l|}{ Unknown } \\
\hline ECL 11.543 & 1.8 & 1.4 & $\operatorname{tr}$ & 1.5 & 1.5 \\
\hline ECL 13.565 & 3.2 & 2.1 & 1.1 & 2.4 & 2.2 \\
\hline
\end{tabular}

* Summed features represent groups of two or three fatty acids which could not be separated by GLC with the MIDI system. Summed feature 3 contained $\mathrm{C}_{16: 1} \omega 7 c$ and/or iso- $\mathrm{C}_{15: 0} 2-\mathrm{OH}$; summed feature 4 contained iso- $\mathrm{C}_{17: 1} \mathrm{I}$ and/or anteiso- $\mathrm{C}_{17: 1}$.

\section{Description of Flavobacterium fluvii sp. nov.}

Flavobacterium fluvii (flu'vi.i. L. gen. n. fluvii of a river, of a stream).

Cells are Gram-staining-negative rods, $0.7-0.9 \mu \mathrm{m}$ in diameter and 2.0-3.0 $\mu \mathrm{m}$ in length. Colonies on R2A agar are yellow, convex and circular with entire margins. Growth occurs at $15-35{ }^{\circ} \mathrm{C}$ (optimum, $25-30{ }^{\circ} \mathrm{C}$ ), at
$\mathrm{pH}$ 6.0-8.0 (optimum, pH 6.5-7.5). More than $1 \%(\mathrm{w} / \mathrm{v}$ ) $\mathrm{NaCl}$ inhibits growth severely; no growth occurs in the presence of $2 \% \mathrm{NaCl}$. Oxidase- and catalase-positive. Nitrate is not reduced to nitrite. Gliding motility is not observed. Aesculin is hydrolysed. Tween 20, Tween 80, tyrosine, carboxylmethylcellulose, gelatin, casein and starch are not hydrolysed. Flexirubin type pigments are produced. Acid is produced from raffinose, myo-inositol, lactose, Larabinose, arbutin, D-fructose, salicin, D-mannose and Dgalactose, but not from melibiose. In the API 20NE kit, Dglucose, L-arabinose, D-mannose and maltose are assimilated, but D-mannitol, malic acid, potassium gluconate, $\mathrm{N}$ acetylglucosamine, capric acid, adipic acid, trisodium citrate and phenylacetic acid are not assimilated. In the API ZYM kit, alkaline phosphatase, esterase (C4), esterase lipase (C8), acid phosphatase and $\alpha$-glucosidase activities are present and weak enzymic activity is observed for naphthol-AS-BI-phosphohydrolase. No activities are found for lipase (C14), leucine arylamidase, valine arylamidase, cystine arylamidase, trypsin, $\alpha$-chymotrypsin, $\alpha$-galactosidase, $\beta$-glucuronidase, $\beta$-glucosidase, $N$-acetyl- $\beta$-glucosaminidase, $\beta$-galactosidase, $\alpha$-fucosidase or $\alpha$-mannosidase. The type strain is resistant to polymyxin B (100 U), gentamicin $(30 \mu \mathrm{g})$, kanamycin $(30 \mu \mathrm{g})$, oleandomycin $(15 \mu \mathrm{g})$, ampicillin $(10 \mu \mathrm{g})$, chloramphenicol $(100 \mu \mathrm{g})$, streptomycin $(50 \mu \mathrm{g})$, lincomycin $(15 \mu \mathrm{g})$, tetracycline $(30 \mu \mathrm{g})$, carbenicillin $(100 \mu \mathrm{g})$ and novobiocin $(50 \mu \mathrm{g})$, but sensitive to penicillin $\mathrm{G}$ ( $10 \mathrm{U})$. The major isoprenoid quinone is MK-6. The major ( $>5 \%$ of the total fatty acids) cellular fatty acids are iso- $\mathrm{C}_{15: 0}$, anteiso- $\mathrm{C}_{15: 0}$, summed feature $3\left(\mathrm{C}_{16: 1} \omega 7 c\right.$ and/or iso- $\left.\mathrm{C}_{15: 0} 2-\mathrm{OH}\right)$, iso- $\mathrm{C}_{17: 0}$ $3-\mathrm{OH}$ and iso- $\mathrm{C}_{15: 0} 3-\mathrm{OH}$.

The type strain, $\mathrm{H}^{\mathrm{T}}\left(=\right.$ KACC $12818^{\mathrm{T}}=$ DSM $19978^{\mathrm{T}}$ ), was isolated from sediment of the Gazwa stream, Jinju city, South Korea. The DNA G $+\mathrm{C}$ content of the type strain is $37.2 \mathrm{~mol} \%$ (HPLC).

\section{Acknowledgements}

This study was supported by grants from the Environmental Biotechnology National Core Research Center and the 21C Frontier Microbial Genomics and Application Center Program, Ministry of Education, Science \& Technology, Korea.

\section{References}

Bergey, D. H., Harrison, F. C., Breed, R. S., Hammer, B. W. \& Huntoon, F. M. (1923). Genus II. Flavobacterium gen. nov. In Bergey's Manual of Determinative Bacteriology, pp. 97-117. Baltimore: Williams \& Wilkins.

Bernardet, J.-F. \& Bowman, J. (2006). The genus Flavobacterium. In The Prokaryotes: a Handbook on the Biology of Bacteria, 3rd edn, vol. 7, pp. 481-531. Edited by M. Dworkin, S. Falkow, E. Rosenberg, K. H. Schleifer \& E. Stackebrandt. New York: Springer.

Bernardet, J.-F., Segers, P., Vancanneyt, M., Berthe, F., Kersters, K. \& Vandamme, P. (1996). Cutting a Gordian knot: emended classification and description of the genus Flavobacterium, emended description of the family Flavobacteriaceae, and proposal of 
Flavobacterium hydatis nom. nov. (basonym, Cytophaga aquatilis Strohl and Tait 1978). Int J Syst Bacteriol 46, 128-148.

Bernardet, J. F., Nakagawa, Y. \& Holmes, B. (2002). Proposed minimal standards for describing new taxa of the family Flavobacteriaceae and emended description of the family. Int J Syst Evol Microbiol 52, 1049-1070.

Chun, J., Lee, J. H., Jung, Y., Kim, M., Kim, S., Kim, B. K. \& Lim, Y. W. (2007). EzTaxon: a web-based tool for the identification of prokaryotes based on $16 \mathrm{~S}$ ribosomal RNA gene sequences. Int J Syst Evol Microbiol 57, 2259-2261.

Cousin, S., Pauker, O. \& Stackebrandt, E. (2007). Flavobacterium aquidurense sp. nov. and Flavobacterium hercynium sp. nov., from a hard-water creek. Int J Syst Evol Microbiol 57, 243-249.

Ezaki, T., Hashimoto, Y. \& Yabuuchi, E. (1989). Fluorometric deoxyribonucleic acid-deoxyribonucleic acid hybridization in microdilution wells as an alternative to membrane filter hybridization in which radioisotopes are used to determine genetic relatedness among bacterial strains. Int J Syst Bacteriol 39, 224-229.

Felsenstein, J. (2002). PHYLIP (phylogeny inference package), version 3.6a. Distributed by the author. Department of Genome Sciences, University of Washington, Seattle, USA.

Humphry, D. R., George, A., Black, G. W. \& Cummings, S. P. (2001). Flavobacterium frigidarium sp. nov., an aerobic, psychrophilic, xylanolytic and laminarinolytic bacterium from Antarctica. Int $J$ Syst Evol Microbiol 51, 1235-1243.

Jeon, C. O., Park, W., Ghiorse, W. C. \& Madsen, E. L. (2004). Polaromonas naphthalenivorans sp. nov., a naphthalene-degrading bacterium from naphthalene-contaminated sediment. Int J Syst Evol Microbiol 54, 93-97.

Jit, S., Dadhwal, M., Prakash, O. \& Lal, R. (2008). Flavobacterium lindanitolerans sp. nov., isolated from hexachlorocyclohexane-contaminated soil. Int J Syst Evol Microbiol 58, 1665-1669.

Kim, J. M., Le, N. T., Chung, B. S., Park, J. H., Bae, J.-W., Madsen, E. L. \& Jeon, C. O. (2008). Influence of soil components on the biodegradation of benzene, toluene, ethylbenzene, and $o-, m$-, and $p$-xylenes by the newly isolated bacterium Pseudoxanthomonas spadix BD-a59. Appl Environ Microbiol 74, 7313-7320.

Komagata, K. \& Suzuki, K. (1987). Lipid and cell-wall analysis in bacterial systematics. Methods Microbiol 19, 161-207.

Lányí, B. (1987). Classical and rapid identification methods for medically important bacteria. Methods Microbiol 19, 1-67.

Leifson, E. (1963). Determination of carbohydrate metabolism of marine bacteria. J Bacteriol 85, 1183-1184.

Lu, S., Park, M., Ro, H.-S., Lee, D. S., Park, W. \& Jeon, C. O. (2006). Analysis of microbial communities using culture-dependent and culture-independent approaches in an anaerobic/aerobic SBR reactor. J Microbiol 44, 155-161.

McCammon, S. A. \& Bowman, J. P. (2000). Taxonomy of Antarctic Flavobacterium species: description of Flavobacterium gillisiae sp. nov., Flavobacterium tegetincola sp. nov. and Flavobacterium xanthum sp. nov., nom. rev. and reclassification of [Flavobacterium] salegens as Salegentibacter salegens gen. nov., comb. nov. Int J Syst Evol Microbiol 50, 1055-1063.

Park, M., Lu, S., Ryu, S. H., Chung, B. S., Park, W., Kim, C.-J. \& Jeon, C. O. (2006). Flavobacterium croceum sp. nov., isolated from activated sludge. Int J Syst Evol Microbiol 56, 2443-2447.

Park, M., Ryu, S. H., Vu, T. H., Ro, H. S., Yun, P. Y. \& Jeon, C. O. (2007). Flavobacterium defluvii sp. nov., isolated from activated sludge. Int J Syst Evol Microbiol 57, 233-237.

Rosselló-Mora, R. \& Amann, R. (2001). The species concept for prokaryotes. FEMS Microbiol Rev 25, 39-67.

Ryu, S. H., Park, M., Jeon, Y., Lee, J. R., Park, W. \& Jeon, C. O. (2007). Flavobacterium filum sp. nov., isolated from a wastewater treatment plant in Korea. Int J Syst Evol Microbiol 57, 2026-2030.

Ryu, S. H., Park, J. H., Moon, J. C., Sung, Y., Lee, S. S. \& Jeon, C. O. (2008). Flavobacterium resistens sp. nov., isolated from stream sediment. Int J Syst Evol Microbiol 58, 2266-2270.

Smibert, R. M. \& Krieg, N. R. (1994). Phenotypic characterization. In Methods for General and Molecular Bacteriology, pp. 607-654. Edited by P. Gerhardt, R. G. E. Murray, W. A. Wood \& N. R. Krieg. Washington, DC: American Society for Microbiology.

Tamaki, H., Hanada, S., Kamagata, Y., Nakamura, K., Nomura, N., Nakano, K. \& Matsumura, M. (2003). Flavobacterium limicola sp. nov., a psychrophilic, organic-polymer-degrading bacterium isolated from freshwater sediments. Int J Syst Evol Microbiol 53, 519-526.

Tamaoka, J. \& Komagata, K. (1984). Determination of DNA base composition by reversed-phase high-performance liquid chromatography. FEMS Microbiol Lett 25, 125-128.

Thompson, J. D., Higgins, D. G. \& Gibson, T. J. (1994). CLUSTAL W: improving the sensitivity of progressive multiple sequence alignment through sequence weighting, position-specific gap penalties and weight matrix choice. Nucleic Acids Res 22, 4673-4680.

Van Trappen, S., Vandecandelaere, I., Mergaert, J. \& Swings, J. (2005). Flavobacterium fryxellicola sp. nov. and Flavobacterium psychrolimnae sp. nov., novel psychrophilic bacteria isolated from microbial mats in Antarctic lakes. Int J Syst Evol Microbiol 55, 769772.

Vela, A. I., Fernandez, A., Sánchez-Porro, C., Sierra, E., Mendez, M., Arbelo, M., Ventosa, A., Domínguez, L. \& Fernández-Garayzábal, J. F. (2007). Flavobacterium ceti sp. nov., isolated from beaked whales (Ziphius cavirostris). Int J Syst Evol Microbiol 57, 2604-2608.

Weon, H. Y., Song, M. H., Son, J. A., Kim, B. Y., Kwon, S. W., Go, S. J. \& Stackebrandt, E. (2007). Flavobacterium terrae sp. nov. and Flavobacterium cucumis sp. nov., isolated from greenhouse soil. Int $J$ Syst Evol Microbiol 57, 1594-1598.

Zhu, F., Wang, S. \& Zhou, P. (2003). Flavobacterium xinjiangense sp. nov. and Flavobacterium omnivorum sp. nov., novel psychrophiles from the China No. 1 glacier. Int J Syst Evol Microbiol 53, 853-857. 